\title{
The Valuation of Relationship between EPS, GST and Demonetization of Indian Industries
}

\author{
Angelin Kiruba, S. Vasantha
}

\begin{abstract}
To determine the valuation of companies' shares, the individual always consider the earning per share (EPS). There are lot of literature review provides the information of how much the individual investors considering the importance of earnings per shares before their investment to one industries. Earnings per shares will help the investors to analyse on the growth of their investment from the company. The total number of outstanding shares will divide the net income of the company to find the value of the EPS. This tool used by all the security market investors before they are purchasing the shares. There are lot of research gone through by various researcher by using the EPS to determine the share price of various industries across the globe. In India, after the implementation of GST and demonetisation there are plenty of assumption and expectation spread across regarding the GDP of the country, Profit of the business and also the performance of share market. People are not aware what was the earnings of each individual received when they did investment during this period. This paper analyse how much the EPS value has been received by the investors of security market after the implementation of GST and demonetisation.
\end{abstract}

Keywords : GST, Demonetisation, EPS, relationship analysis.

\section{INTRODUCTION}

Goods and Service Tax launched in July 2017. It is an indirect tax collected by central and state government. GST will be collected on every transaction of business and services and also the exports and imports. It will replace all other indirect tax such as VAT, service tax and excise duty etc. It is a value addition tax which is the taxable amount of transaction. These kind of policy changes in the government will affect the global market and business sectors. However Indian government took the risk of removing all other taxes and created as single tax. That is GST.

After the implementation of demonetization, the government is shared the reason for under taken this act is to control the illegal activity and terrorism. And the government called this as action of shadow economy. Even though it was taken for the good reason, the Indian share market has been faced the big challenges at the time of implementation. The BSE value is reduced around 1689 points and the NIFTY has been reduced by 541 points. So it was needed to understand the share price changes before and after the implementation of demonetisation.

Earnings per share represents the earnings from the

Revised Manuscript Received on July 22, 2019.

Angelin Kiruba, Ph.D.Research Scholar, School of Management Studies,Vels Institute of Science, Technology \& Advanced Studies(VISTAS), Chennai, India.

Dr. S. Vasantha, (Corresponding Author), Professor \& Research Supervisor, School of Management Studies, Vels Institute of Science, Technology \& Advanced Studies(VISTAS), Chennai, India company's share. Net tax, dividends are allocated to all the shares. The table has been calculated by dividing the net income using out standing shares during the period. Since the outstanding shares will get vary from time to time, the quarterly and annually shares has been used.

This study will help to analyse whether any strong relationship is available between the tax reconstruction that is GST and the demonetisation of currency when providing the EPS.

\section{REVIEW OF LITERATURE}

Angelin Kiruba, Dr. S. Vasantha(2018) ICIRST-18, the selected industries were used for the research to find out the impact of demonetisation in share market of Indian industries. It was found that there is strong impact in the share market during the demonetisation period for the short period of time.

Sunil Tanej and Pratibha Bhardwaj (2018), has done the research on the impact of GST in the IT sector. The objective of the study were to know how the GST is works and to know the features of the GST.And also the impact of GST on IT sector. This study also extended to find the tax rates after the impact of GST. From the various review and the rate of GST, the author is concluded the research as IT sector has the good benefits due to the GST. And it creating the profit in the IT sector.

Rajanish Kumar (2017) has done the research on effect of demonetisation on stocks in terms of EPS. For his research he has taken the data from January to March. The main objective of the research is to find whether any long term impact in EPS due to the demonetisation act. However from the result it was found, there is no long term impact in the share prices due to the demonetisation.

Manas Chakravarty (2017) ,based on his research the demonetisation effect is the temporary. Since the interest percentage is low, it has been created the adverse effect. And also he found that it is not only the demonetisation affected the Indian share prices. During that time, there were US president election occurred. So it created the huge impact on the growing country like India.

Livemint (2017) has done the research on the impact of the GST created the effect in the home currency on exports. From that it found that the exports values are slow in the June quarter and the Indian rupee is strengthened $5.16 \%$ against the dollar since January and may. And they found implementation of GST affected the lot of sectors during the period.

According to UBS(2017), earnings could disappoint further. It believes risk-reward is unfavourable with markets at peak valuations and continued

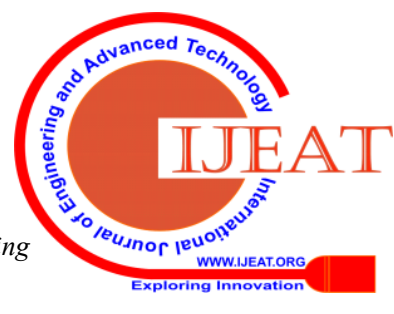


low earnings growth. Though Indian markets have outperformed peers this year, elevated valuations, weak economy and elusive earnings growth have started to worry foreign investors which led to a sell-off by foreign institutional investors (FIIs) in August and September.

Sukanta Sarkar (2010) conducted a study on the parallel economy in India. In this study, she examined about the causes and impact of the demonetisation act in India. As per her research she found that government has been given the importance on the implementation of demonetisation. So she has concluded her research with the following suggestion. That is government might have formed a committee before introducing the demonetisation. So that they can control the black money properly.

Tax Research Team (2016), was done the research on the demonetisation effect in the Indian economy. In that they analysed all the impact of the demonetisation during those period. As per their research it was found that, demonization is affected the credit level, spending level and the government finances and also it was affected the all the level of daily activity.

Dr. Vandana Gupta, Utsav Asher, Hunny Jain(2017), has done the research on the due to demonetisation how the performance of the BSE. For analysis they have used the 50 companies data which are listed in the BSE. Paired comparison T-test has been used to find the demonetisation changes in the stock price before and after in the share market. Form the result it was clearly understood that 54 percentage the companies are affected during the demonetisation period.

\section{RESULTS AND FINDINGS}

The price-to-earnings (PE) and price-to-book value (PBV) ratios are favourite tools of value investors.

The short code used here is Profit before tax $(\mathrm{P} / \mathrm{B})$, Earnings per share (EPS) and Return on Equity (RoE).

\section{Hypothesis}

This is used to validate the impact of share values before and after the demonetisation and GST.

Before and after the one month of share value has been used to analyse the changes demonetisation. For GST April 2017 to Dec 2017 data was used. For EPS Apr 2017 to Mar 2018 data has been used.

H0: $(\mu 1=\mu 2=\mu 3)$ Mean return are equal there is no changes in the stock values.

$\mathrm{H} 1$ : Mean returns are not equal. There is a change in the share values after the demonetisation and GST.

EPS:

$$
E P S=(\text { net income }- \text { dividends on preferred stock }) / \text { average outstanding common shares }
$$

EBT:

$$
\text { EBT }=\text { Net income }+ \text { Corporate Income Tax }
$$

ROE

$$
\mathrm{ROE}=\text { Net income } \div \text { shareholder's equity }
$$

\section{Personal Care industry:}

\begin{tabular}{|l|r|r|r|r|r|}
\hline & Degree of freedom & Sum of Squares & Mean Square & F-Test & Significance of F \\
\hline Between Group Design & 1 & 156.44 & 156.44 & 11.93 & 0.003 \\
\hline Within Subject Design & 14 & 153.56 & 13.11 & & \\
\hline Total & 15 & 340 & & & \\
\hline
\end{tabular}

Table- 1 (Demonetisation)

\section{Inference:}

Given Sig. $<0.05$, (Value $=0.0038$ ), it means the data is accepting the H1 hypothesis. The three segment analysis shows the result as insignificant. From the above table, we could see the results are significantly difference. It means that personal care industries shares are affected during the demonetisation period. 


\begin{tabular}{|l|r|r|}
\hline \multicolumn{3}{|c|}{ Personal Care } \\
\hline Companies & F & \\
\hline Dabur & 0.12 & Significance $\boldsymbol{F}$ \\
\hline HUL & 0.63 & 0.73 \\
\hline Colgate & 0.04 & 0.45 \\
\hline Godrej consumer & 0.09 & 0.84 \\
\hline Marico & 0 & 0.77 \\
\hline
\end{tabular}

Table- 2 (GST)

Given Significant 0.05, all industries values are greater than GST the share return has not been changed. It means that GST the 0.05 or equal to 0.05 .It means that, Colgate, Marico, is not creating any difference in the share values of personal Dabur, HUL and Godrej Consumer companies are after the care industries.

\begin{tabular}{|l|r|r|r|r|r|}
\hline \multicolumn{7}{|c|}{ Personal Care } \\
\hline Companies & 6 Months Average Volume & P/B & Dividend Yield (\%) & Book Value (INR) & EPS (INR) \\
\hline Hindustan Unilever & 1171306 & 39.28 & 0.01 & 35.89 & 23.41 \\
\hline Godrej Consumer & 569495 & 12.62 & 0.01 & 85.16 & 20.65 \\
\hline Colgate & 326271 & 17 & 0.91 & 64.61 & 23.06 \\
\hline Dabur India & 1550304 & 10.71 & 0.01 & 31.84 & 7.33 \\
\hline Marico & 1078436 & 13.77 & 1.11 & 22.97 & 6.22 \\
\hline
\end{tabular}

Table- 3

\begin{tabular}{|l|r|r|r|r|r|r|r|}
\hline \multicolumn{9}{|c|}{ Personal Care } \\
\hline Companies & Market Cap (Cr) & Revenue (Cr) & Net Profit (Cr) & Net Margin \% & RoE \% & Price to Book & Price to Earnings \\
\hline Dabur & 60067.85 & 60067.85 & 7630.11 & 1293.87 & 28.97 & 10.71 & 46.52 \\
\hline Colgate & 29876.26 & 29876.26 & 4413.17 & 627.18 & 14.09 & 17 & 47.64 \\
\hline Marico & 40836.5 & 6175.15 & 816.34 & 13.04 & 37.51 & 13.77 & 50.88 \\
\hline Godrej Consumer & 73205.45 & 9897.59 & 1406.14 & 14.06 & 27.37 & 12.62 & 52.03 \\
\hline Hindustan Unilever & 305133.62 & 35007 & 5068 & 14.25 & 67.8 & 39.28 & 60.21 \\
\hline
\end{tabular}

Table- 4

According to father of Investing Benjamin Graham, the good investors get their benefit when they do their investment in the long term projects. As everyone aware the earnings per share will be in the growing in some point of time, when the investor wait for it. As per the above table 1 to 4 of personal care industry, during the demonetisation period there is a significant level of changes in the shares. But when we

\section{Transport and Logistics:}

compare it with the GST period, it is not created any difference to the shares. And also we could see all companies shares are earned the dividend even though the market has been faced the big challenges like GST and demonetisation, it is not created any negative impact of the shares of personal care.

\begin{tabular}{|l|r|r|r|r|r|}
\hline & Degree of freedom & Sum of Squares & Mean Square & F-Test & Significance of F \\
\hline Between Group Design & 1 & 31.21 & 31.21 & 1.41 & 0.25 \\
\hline Within Subject Design & 14 & 308.79 & 22.06 & & \\
\hline Total & 15 & 340 & & & \\
\hline
\end{tabular}

Table- 5( Demonetisation)

\section{Inference:}

Given Sig. $<0.05$, (Value $=0.025)$, shows the result of three different period mean return are shows the different values.
So we have to accept the $\mathrm{H} 1$ hypothesis.The result are significantly difference. It means that transport and logistics industries also affected due to demonetisation.

\begin{tabular}{|c|c|c|}
\hline \multicolumn{3}{|c|}{ Transport and Logistics } \\
\hline Companies & \begin{tabular}{|l|l|}
$\boldsymbol{F}$ \\
\end{tabular} & Significance $F$ \\
\hline Interglobe & 0.31 & 0.59 \\
\hline Container Corp & 5.62 & 0.04 \\
\hline Jet airways & 0.37 & 0.56 \\
\hline SpiceJet & 0.05 & 0.81 \\
\hline Aegis logistics & 0.43 & 0.52 \\
\hline
\end{tabular}

Table- 6(GST) 
From the Table 6, except Container Corp all other industries values are greater than the 0.05 . It means that GST is not created the difference of share market in the transport and logistics industry.

\begin{tabular}{|l|r|r|r|r|r|}
\hline \multicolumn{7}{|c|}{ Transport and Logistics Industry } \\
\hline Companies & 6 Months Average Volume & P/B & Dividend Yield (\%) & Book Value (INR) & EPS (INR) \\
\hline Interglobe & 741439 & 8.1 & 2.33 & 180.35 & 66.73 \\
\hline Container Corpn & 323795 & 3.38 & 1.05 & 386.38 & 44.77 \\
\hline Jet airways & 4129797 & -2.85 & 0 & -218.59 & 26.87 \\
\hline Spicejet & 1845537 & -84.41 & 0 & -1.6 & 9.26 \\
\hline Aegis Logistics & 402757 & 9.62 & 0.37 & 29.25 & 5.26 \\
\hline
\end{tabular}

Table- 7

Transport and Logistics Industry

\begin{tabular}{|l|r|r|r|r|r|r|r|}
\hline Companies & Market Cap (Cr) & Revenue (Cr) & Net Profit (Cr) & Net Margin \% & RoE \% & Price to Book & Price to Earnings \\
\hline Interglobe & 56138.77 & 22069.99 & 2565.04 & 11.13 & 44.55 & 8.1 & 21.89 \\
\hline Jet airways & 7081.66 & 22810.81 & 305.18 & 1.28 & 0 & -2.85 & 23.2 \\
\hline Spicejet & 8095.57 & 7395.99 & 555.28 & 7.39 & 0 & -84.41 & 14.58 \\
\hline Container Corpn & 31782.01 & 6084.42 & 1091.11 & 17.03 & 9.68 & 3.38 & 29.13 \\
\hline Aegis Logistics & 9400.43 & 4806.82 & 191.4 & 3.98 & 24.22 & 9.62 & 53.48 \\
\hline
\end{tabular}

\section{Table- 8}

As per the above table 5 to 8 of transport and logistics shares are earned the dividend. But here we are able to see the industry, during the demonetisation period there is a negative impact in the profit and in the book value of Jet significant level of changes in the shares. But when we airways and in the Spicejet which clearly shows the compare it with the GST period, it is not created any relationship of new policy given by the government is always difference to the shares. And also we could see all companies has the relationship in the share market.

\section{Hotel Industry}

\begin{tabular}{|l|r|r|r|r|r|}
\hline & Degree of freedom & Sum of Squares & Mean Square & F-Test & Significance of F \\
\hline Between Group Design & 1 & 1.45 & 1.45 & 0.06 & 0.81 \\
\hline Within Subject Design & 14 & 338.55 & 24.18 & & \\
\hline Total & 15 & 340 & & & \\
\hline
\end{tabular}

Table - 9 (Demonetisation)

\section{Inference:}

Given Sig. $>0.05$, (Value $=0.80)$, the mean return are shows the equal value in the three different windows. It means that we have to accept the $\mathrm{H} 0$ null hypothesis. On analysing the multi comparison table, the mean value is not significantly different. It means that share price of hotel sector is changed before, after and during the demonetisation in the hotel sector.

\begin{tabular}{|l|r|r|}
\hline Hotel Industry \\
\hline Companies & \multicolumn{1}{|c|}{ S } & \\
\hline Hotel-ElH & 1.08 & 0.33 \\
\hline India tourism D & 0.51 & 0.49 \\
\hline Indian Hotels & 0 & 0.97 \\
\hline Leela & 2.7 & 0.15 \\
\hline Mahindra Holiday & 0.28 & 0.61 \\
\hline
\end{tabular}

Table-10(GST)

From the above table-10, the given significant has not been met with any of the company. It will be the another example of the GST is not created any difference in the Hotel industries shares. When comparing with other industries, hotel industry shares were not changes even in the demonetisation period also.

\begin{tabular}{|l|r|r|r|r|r|}
\hline \multicolumn{7}{|c|}{ Hotel Industry } \\
\hline Companies & 6 Months Average Volume & P/B & Dividend Yield (\%) & Book Value (INR) & EPS (INR) \\
\hline ElH Associated Hotels & 27614 & 5.35 & 0.89 & 94.18 & 13.31 \\
\hline India Tourism Devp & 65521 & 10.72 & 0.29 & 43.29 & 3.21 \\
\hline Indian Hotels & 2142991 & 4 & 0.24 & 34.5 & 0.55 \\
\hline Hotel Leelaventure & 806948 & 89.93 & 0 & 0.21 & 0.1 \\
\hline Mahindra Holidays & 118281 & 5.58 & 1.11 & 54.02 & 9.56 \\
\hline
\end{tabular}

Table-11 


\begin{tabular}{|l|r|r|r|r|r|r|r|}
\hline \multicolumn{9}{|c|}{ Hotel Industry } \\
\hline Companies & Market Cap (Cr) & Revenue (Cr) & Net Profit (Cr) & Net Margin \% & RoE \% & Price to Book & Price to Earnings \\
\hline EIH Associated Hotels & 1533.92 & 266.46 & 40.56 & 14.74 & 16.34 & 5.35 & 37.81 \\
\hline Mahindra Holidays \& Resorts & 4019.33 & 1091.58 & 127.62 & 11.43 & 26.37 & 5.58 & 31.49 \\
\hline India Tourism Devp & 3980.99 & 377.71 & 21.96 & 6.82 & 2.94 & 10.72 & 144.44 \\
\hline Indian Hotels & 16393.93 & 4005.62 & 38.25 & 0.94 & -3.26 & 4 & 251.17 \\
\hline Hotel Leelaventure & 1210.66 & 710.45 & 5.99 & 0.81 & 0 & 89.93 & 202.11 \\
\hline
\end{tabular}

\section{Table-12}

From the above table 11 to 12 of Hotel industry, during the demonetisation period there is no significant level of changes in the shares. When we compare it with the GST period, it is not created any difference to the shares. And we could see all companies shares are earned the dividend. But here we are able to see the negative impact in the return on earnings in the
Indian Hotels which clearly shows the relationship of new policy given by the government is always has the relationship in the share market. However, it is not affected the profit earnings of the company. It gave the high earnings to the shares when comparing the peer competitors of this field.

\section{Food Processing:}

\begin{tabular}{|l|r|r|r|r|r|}
\hline & Degree of freedom & Sum of Squares & Mean Square & F-Test & Significance of F \\
\hline Between Group Design & 1 & 223.71 & 223.71 & 26.93 & 0.0001 \\
\hline Within Subject Design & 14 & 116.29 & 8.31 & & \\
\hline Total & 15 & 340 & & & \\
\hline
\end{tabular}

Table - 13 (Demonetisation)

\section{Inference:}

Given Sig. $<0.05,($ Value $=0.00013)$, the result clearly shows to accept the $\mathrm{H} 1$ hypothesis. Because mean return of the three windows are not equal. And also the multi comparison table shows the stock returns are changed in all the three period of time. So food processing is affected due to the demonetisation.

\begin{tabular}{|l|r|r|}
\hline \multicolumn{3}{|c|}{ Food Processing } \\
\hline Companies & F & Significance $\boldsymbol{F}$ \\
\hline Britannia & 0 & 0.92 \\
\hline GlaxoSmith Con & 0.52 & 0.49 \\
\hline Hatsun Agro & 2.53 & 0.16 \\
\hline Kwality & 2.47 & 0.16 \\
\hline Nestle & 0.08 & 0.77 \\
\hline
\end{tabular}

Table - 14 (GST)

From the above table we are able to see all the companies share values are greater than the 0.05 . There is no significant difference happened in the food processing sector due to the
GST implementation. But we are able to see the changes in the food processing when the time of demonetisation.

\begin{tabular}{|l|r|r|r|r|r|}
\hline \multicolumn{7}{|c|}{ Food Processing } \\
\hline Companies & 6 Months Average Volume & P/B & Dividend Yield (\%) & Book Value (INR) & EPS (INR) \\
\hline Britannia & 173901 & 19.91 & 0.42 & 261.49 & 79.26 \\
\hline Glaxosmithkline Consumer & 21624 & 7.72 & 1.17 & 775.91 & 157.93 \\
\hline Hatsun Agro & 81237 & 31.01 & 0.54 & 23.87 & 8.65 \\
\hline Kwality & 3366273 & 1.36 & 0.16 & 44.85 & 4.4 \\
\hline Nestle India & 61406 & 24.5 & 0.99 & 354.77 & 127.07 \\
\hline
\end{tabular}

Table -15

Food Processing

\begin{tabular}{|l|r|r|r|r|r|r|r|}
\hline Companies & Market Cap (Cr) & Revenue (Cr) & Net Profit (Cr) & Net Margin \% & RoE \% & Price to Book & Price to Earnings \\
\hline Britannia & 62494.39 & 9768.7 & 951.11 & 9.58 & 37 & 19.91 & 65.68 \\
\hline Glaxosmithkline Consumer & 25191.06 & 4404.63 & 664.18 & 14.28 & 22.18 & 7.72 & 37.93 \\
\hline Nestle India & 83807.43 & 10192.18 & 1225.19 & 11.82 & 31.78 & 24.5 & 68.4 \\
\hline Hatsun Agro & 11264.26 & 4466.16 & 131.68 & 2.94 & 46.51 & 31.01 & 85.54 \\
\hline Kwality & 1451.61 & 6550.29 & 104.68 & 1.6 & 20.05 & 1.36 & 13.87 \\
\hline
\end{tabular}


From the above table 12 to 16 of food processing industry, during the demonetisation period there is a difference in the shares. When we compare it with the GST period, it is not created any difference to the shares. And we could see all companies shares are earned the dividend which explains the 5. Domestic Appliance:

\begin{tabular}{|l|r|r|r|r|r|}
\hline & Degree of freedom & Sum of Squares & Mean Square & F-Test & Significance of F \\
\hline Between Group Design & 1 & 250.46 & 250.46 & 39.16 & 0.00002 \\
\hline Within Subject Design & 14 & 89.54 & 6.39 & & \\
\hline Total & 15 & 340 & & & \\
\hline
\end{tabular}

Table -17

\section{Inference:}

Given Sig. $<0.05,($ Value $=0.00013)$, which shows the result of accepting the $\mathrm{H} 1$ hypothesis. All the three windows are not equal. Based on the multi comparison table, it is also shows healthy level of trading happened in the food processing sector. Since it is forming under the Maslow's basic needs sector, it was not created any impact to the shareholders who invested in the food processing sector.

\begin{tabular}{|l|r|r|}
\hline \multicolumn{3}{|c|}{ Domestic Appliance } \\
\hline Companies & $\boldsymbol{F}$ & Significance $\boldsymbol{F}$ \\
\hline Bajaj Electric & 0.55 & 0.48 \\
\hline Butterfly & 1.92 & 0.21 \\
\hline Hawkins Cooker & 1.82 & 0.22 \\
\hline TTK Prestige & 0.19 & 0.67 \\
\hline Viaan Ind & 0.96 & 0.36 \\
\hline
\end{tabular}

Table - 18

From the above table 18, clearly a explains that the GST But we could see the price value of the shares are not implementation is not created any difference in the above decreased as well not been into the booming value due to the mentioned companies. Across the country, there is an remarkable tax reconstruction done by the Indian assumption of GST will increase the product selling prices. government.

\begin{tabular}{|l|r|r|r|r|r|}
\hline \multicolumn{7}{|c|}{ Domestic Appliance } \\
\hline Companies & 6 Months Average Volume & P/B & Dividend Yield (\%) & Book Value (INR) & EPS (INR) \\
\hline Bajaj Electricals & 635644 & 6.86 & 0.45 & 90.02 & 11.24 \\
\hline Butterfly & 110741 & 5.06 & 0 & 102.21 & -9.24 \\
\hline Hawkins Cookers & 1510 & 15.16 & 2.5 & 184.67 & 91.25 \\
\hline TTK Prestige & 9015 & 7.71 & 0.41 & 843.87 & 243.62 \\
\hline Viaan Industries & 335559 & 7.84 & 0 & 4.47 & 2.35 \\
\hline
\end{tabular}

Table-19

\begin{tabular}{|c|c|c|c|c|c|c|c|}
\hline \multicolumn{8}{|c|}{ Domestic Appliance } \\
\hline Companies & Market Cap (Cr) & Revenue $(\mathrm{Cr})$ & Net Profit (Cr) & Net Margin \% & RoE \% & Price to Book & Price to Earnings \\
\hline Bajaj Electricals & 6301.84 & 4388.18 & 114.73 & 2.59 & 13.51 & 6.86 & 54.93 \\
\hline TTK Prestige & 7520.04 & 1825.16 & 281.41 & 15.34 & 19.16 & 7.71 & 26.72 \\
\hline Butterfly & 924.1 & 531.25 & -16.52 & -3.09 & -26.83 & 5.06 & Nil \\
\hline Hawkins Cookers & 1480.22 & 565.39 & 48.25 & 8.37 & 54.38 & 15.16 & 30.68 \\
\hline Viaan Industries & 378.41 & 249.97 & 25.46 & 10.06 & 58.6 & 7.84 & 14.86 \\
\hline
\end{tabular}

\section{Table-20}

From the above table 17 to 20 of Domestic Appliance industry, during the demonetisation period there is a significant level of changes in the shares. When we compare it with the GST period, it is not created any difference to the shares. And we could see except Butterfly company, all companies provided the dividend. But here we are able to see the negative impact in the net profit of the Butterfly company which resulted to the nil performance of the share's earnings. Even though the company earned the revenue, it is resulted with the net loss during this validation.

\section{DISCUSSION}

As per the research done by Economic Times, GST has created more than hundred plus industries confirmed their profit gain during this period. At the time of demonetisation, there are plenty of research done by the researcher on the analysing on the business impact. More than two months, the whole business of retail and manufacturing faced the fluctuations. 
Based on the research of Business Standard, Banking was the biggest successful sector after the implementation of demonetisation. When comparing with the GST and Demonetisation, both are in the opposite site. Based on this analyse we able to see demonetisation has created the more effect than the GST. We were trying to find out what will be impact of Indian industries after government brought into the such big changes of taxation and the challenges of demonetisation.

As confirmed by the Benjamin Graham, EPS will take some time after the time of investigation. Considering this fact we have used the data from 2017 - 2018, to find out whether any relationship between EPS, GST and demonetisation of the share market.

Based on the analysis, we able to see Butterfly from Domestic Appliance sector has been affected more during this period. It was not able to give any EPS to their shareholders. Even though it was continuously registered the EPS in the past 10 years, it was failed to provide EPS in the last financial year 2017-2018. Likewise, Jetways and Spicejet from the Transport and Logistics industries rate of earnings were registered as zero in the last financial year. However it was not disappointed the shareholders of their company. It gave the EPS to the shareholders. When we consider the Hotel industry, it was given the significant changes in the share value during the time of demonetisation. But when consider about the EPS, Indian hotel and the hotel Leela was announced the rate of earnings is not more than the zero. Food processing and the personal care industries are in the safer zone. It was not gone with any of the negative impression in the last year, even though all other segment faced the big challenges.

\section{CONCLUSION}

The study used the Data from April 2017 to Dec 2017 has been used to validate the changes of share values during the GST announcement. 8th Nov 2016 before and after a week of data used to analyse the difference of Demonetisation. Likewise data from 2014 , is used for find out the EPS value growth in the past three years. And also we analysed the past ten years details of financial statement of the companies for the industries which is given the negative results in the EPS. All the shareholder when they buy their shares, they have only one goal that is to gain some profit from their investment. The gain of the investment is validated with the EPS. It is the basic analysis everyone do before they purchase their shares. This study is helps understand whether any relationship available between government policy and new announcement like GST and demonetisation. Based on our research we able to find out , the strong relationship between three of them. Even though the share fluctuations is not more like the way everyone assumed, it created the greater impact on the earnings of the shares. The profit earnings percentage are slightly down at the end of the financial year. Since there is no market changes of War announcement, recession, loss on GDP and any other new changes announced by RBI, we believe the loss on profit registered in the Domestic Appliance, Transport and logistics and Hotel industries. At least one company from these industry has been affected due to GST and demonetisation. The basic needs of Health and Food processing sector was in the safer zone due to the mandatory need of living. From this we can conclude that there is a strong relationship available between GST, demonetisation and EPS of the various companies shares.

\section{REFERENCES}

1. Angelin Kiruba and S. Vasantha(2018) Impact of Demonetization on Stocks Market in Indian Industries International Journal of Pure and Applied Mathematics Volume 118 No. 5 2018, 99-115 ISSN: 1311-8080

2. Anushya, \& Karam, P. N. (2014). Indian Indirect Tax Systems' Reforms and Goods and Services Tax. Advancement In Management, 9-14.

3. Aharony, J., \& Swary, I. (1980). Quarterly dividend and earnings announcements and stockholders'returns: An empirical analysis. Journal of Finance, 35(1), 1-12.

4. Bansal, A. (2010). The Indian GST is moving towards the best real-world model of the tax. International Journal of Management Prudence, 1(2), 65-70.

5. Ball, R., \& Shivakumar, L. (2008). How much new information is there in earnings? Journal of Accounting Research, 46, 975-1016.

6. Booth, G., Kallunki, J., Sahlstro, P., \& Tyynela, J. (2011). Foreign vs domestic investors and the postannouncement drift. International Journal of Managerial Finance, 7, 220-237.

7. Brav, A. (2000). Inference in long horizon event studies: A Bayesian approach with application to initial public offerings. The Journal of Finance, 55, 1979-2016.

8. Belle, M. I., \& Freudenber, B. (2015). Calm waters: GST and cash flow stability for small businesses in Australia. eJournal of Tax Research, 13(2), 492-532.

9. Mehra P (2015) Modi govt.'s model for GST may not result in significant growth push. The Hindu.

10. M. Sehrawat, U. Dhanda (2015), "GST in India: A key tax reform", "International journal of research granthaalayah", vol.3, issue 12, December 2015.

11. N. Kumar (2014): "Goods and service tax in India-A way forward", "Global Journals of multidisciplinary studies", vol.3, issue 6, may 2014.

12. R, karthik., Miruthula. A, and Nitheeswari. N. "Web Based Online Machine Controlling And Monitoring Using Plc Via Modbus Communication." International Journal of Communication and $\begin{array}{llll}\text { Computer } & \text { Technologies } & 7.2 & \text { (2019), 22-26. }\end{array}$ doi:10.31838/ijccts/07.02.06 